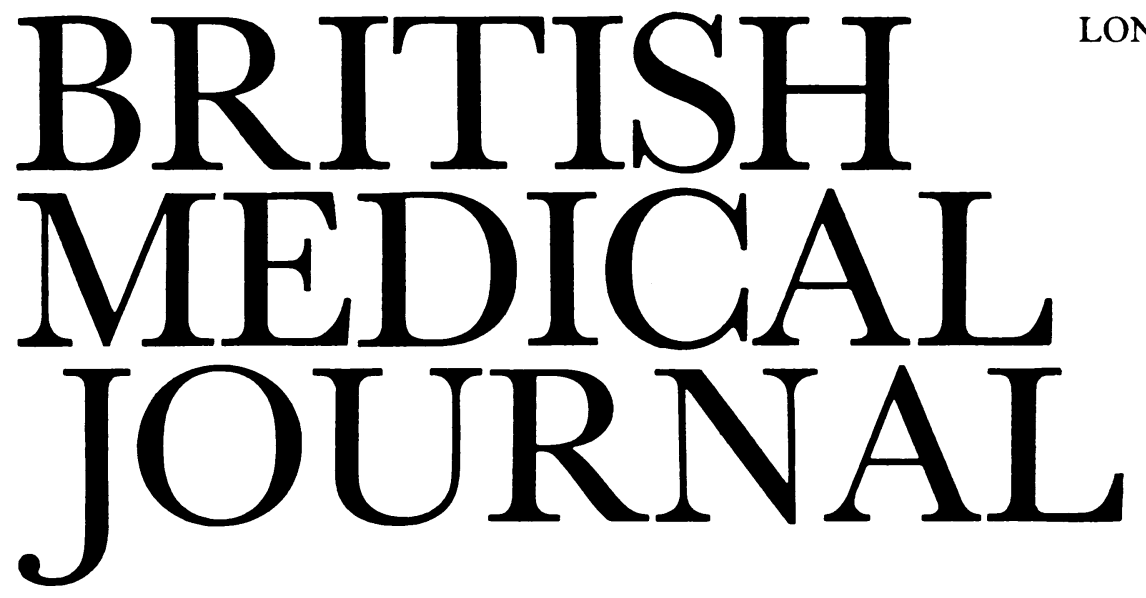

LONDON, SATURDAY 13 SEPTEMBER 1986

\title{
Political dissent and "sluggish" schizophrenia in the Soviet Union
}

"It is considered by some governments that if a person does not agree with the views of the state, his sanity must be called into question. Extensive documentation exists on the misuse of psychiatry and psychiatric drugs in the Soviet Union." Amnesty International, Bloch and Reddaway, and the International Association on the Political Use of Psychiatry are others to have cited several hundred people who have recently been confined to psychiatric hospitals in the Soviet Union for "dissident" activities rather than for medical reasons..$^{2--}$ In November 1985 the last of these published a booklet containing details of "all dissenters believed to be currently interned in psychiatric hospitals for political reasons," in which they listed 133 cases in the Soviet Union ("probably only a small proportion of the true total, as most cases never become known in the outside world").' In response to these widely publicised reports of the misuse of psychiatry in the Soviet Union for the repression of political dissent, a motion for the expulsion of the Soviet All-Union Society of Neurologists and Psychiatrists was tabled for the meeting of the World Psychiatric Association in 1984; however, the Soviet body resigned from the World Psychiatric Association in 1983, thus pre-empting debate. ${ }^{8}$

The issues surrounding this tortuous and emotive subject are raised again in a discussion of the political hazards in the diagnosis of "sluggish" schizophrenia-a diagnostic concept virtually limited to the Soviet Union and some other East European countries. ${ }^{9}$ Mersky and Shafran review articles on sluggish schizophrenia from Soviet publications between 1980 and 1984. Though they acknowledge that the diagnosis may be "genuine," they conclude that: "under the influence of an unscrupulous regime the observations put forward could serve as a ready means to label as psychotically ill many energetic and capable citizens who were in disagreement with authority.... They allow for psychiatric disposal, without much other justification, of anyone whose social activism is unacceptable to the psychiatrist who believes in the officially approved system." In fact, this charge has been laid before ${ }^{3+10-12}$; more specifically, Koryagin has reported that the "healthy people" he examined "were diagnosed in one of two ways, as psychopaths $(70 \%)$ or schizophrenics $(30 \%) . " 13$

In the classification of schizophrenia developed at the Institute of Psychiatry of the Academy of Medical Sciences of the USSR, the criterion for differentiation within the group of schizophrenias is the course of the illness. ${ }^{1+16}$ Three main forms are distinguished depending on whether the course is continuous, recurrent, or "mixed"; and these are thought to differ from each other in terms of symptoms, development, response to treatment, and pathogenesis. The subtypes of continuous schizophrenia are (a) "sluggish," $(b)$ "moderately progressive (paranoid)," and (c) "malignant juvenile." Epidemiologically the annual incidence of schizophrenia in the Soviet Union has been estimated at 0.2 per 1000 , with a point prevalence at 3.8 and at 5.3 per 1000 estimates that are within the range of others for this disorder in the rest of Europe. ${ }^{17}$

Moscow was one of nine field research centres which took part in the International Pilot Study of Schizophrenia. ${ }^{15}$ Some $18 \%$ of the patients with a diagnosis of schizophrenia in the Moscow centre were classified as having sluggish schizophrenia, a diagnosis, however, that was not recorded at any other field research centre. By the standards of the present state examination (a structured psychiatric interview used in the international pilot study) the most prominent symptoms among patients with sluggish schizophrenia were affect laden thoughts, incongruity of affect, flatness, and neurasthenic complaints, with depressed or elated mood. Over four fifths of these patients were rated as having thought blocking, more than three fifths as showing lack of insight, and more than half as having stereotypes of speech. The CATEGO computer classification of their ratings on the present state examination placed virtually all in the classes of manic and depressive disorders.

For comparison among the field research centres sluggish schizophrenia was assigned to the category of latent schizophrenia in the International Classification of Diseases. Four of the other eight centres had patients in this category, all making up less than $6 \%$ of the total. The glossary to the mental disorders section of the ninth revision of the International Classification of Diseases describes latent schizophrenia as follows: "It has not been possible to produce a generally acceptable description of this condition. It is not recommended for general use, but a description is provided for those who believe it to be useful: a condition of eccentric or inconsequent behaviour and anomalies of affect which give the impression of schizophrenia though no definite 
and characteristic schizophrenic anomalies, present or past, have been manifest. The terms indicate that this is the best place to classify some other poorly defined varieties of schizophrenia." 18

Although some Soviet psychiatrists manifestly resist what they find to be abuses of their profession, ${ }^{1319}$ in Britain and the West there is a range of opinion among psychiatrists, from belief that their colleagues in the Soviet Union will knowingly incarcerate perfectly sane dissidents to belief that at least some Soviet psychiatrists genuinely think that some dissidents are suffering from a mental disorder. In the absence of independent information many will probably agree with Windholz's assessment that "No final conclusion about the extent of political motivation in psychiatric commitment cases in the Soviet Union can be made without a well documented analysis of contemporary Soviet commitment practices." 20

Two general aspects of this problem are, however, clear. Firstly, the ethical controversies aroused in all countries by the compulsory detention and treatment of people in psychiatric institutions are heightened when the Soviet Union is considered, because literary ${ }^{21}$ and historical ${ }^{20}$ parallels-as well as contemporary accounts $\mathrm{s}^{2-7} 10-1319$-suggest that the misuse of psychiatry there is deep rooted and long established; because of the cultural, political, legal, and social conditions in that country; because of the lack of knowledge about Soviet medical ${ }^{22}{ }^{23}$ and psychiatric practices, ${ }^{23-29}$ especially those regarding compulsory confinement in "special" as well as "ordinary" psychiatric hospitals ${ }^{23}$; and, particularly, because of the close relationship between psychiatry and the state in the Soviet Union. Secondly, the use of diagnoses such as sluggish schizophrenia exposes fundamental deficiencies in the reliable and valid definition and classification of psychiatric disorders. This is underlined by the fact that in 1983 the World Psychiatric Association published no fewer than 15 different diagnostic criteria for schizophrenia, including that used in the Soviet Union. Overall, the reliability, concordance, and prediction of outcome of such criteria are unsatisfactory, though a few "emerge as relatively effective." 30 Doctors and medical science can make remedial interventions in both these domains; firstly, by continuing to encourage international professional inquiry and enlightenment; and, secondly, by promoting the collaborative research that is still required. ${ }^{3132}$

GREG WILKINSON

Honorary Lecturer,

General Practice Research Unit,

Institute of Psychiatry,

London SE5 8AF

1 British Medical Association. The torture report: report of a working party of the British Medical Association investigating the involvement of doctors in torture. London: British Medical Association, 1986.

2 Amnesty International (British Section). Prisoners of conscience in the USSR: their treatment and conditions (Second ed). London: Quartermaine House, 1980.

3 Bloch S, Reddaway P. Russia's political hospitals: the abuse of psychiatry in the Soviet Union. London: Victor Gollancz, 1977.

London: Victor Gollancz, 1977.
4 Bloch S, Reddaway P. Soviet psychiatric abuse: the shadow over world psychiatry. London: Victor Gollancz, 1984.

5 International Association on the Political Use of Psychiatry. Soviet political psychiatry. The story of the opposition. London: International Association on the Political Use of Psychiatry, 1983.

6 International Association on the Political Use of Psychiatry. Information bulletin No 12 (English edition). London: International Association on the Political Use of Psychiatry, December 1985

7 Working Group on the Internment of Dissenters in Mental Hospitals. Political abuse of psychiatry. $A$ list of victims 30 November 1985. London: International Association on the Political Use of Psychiatry, 1985.

8 Wynn A. The Soviet Union and the World Psychiatric Association. Lancet 1983;i:406-8.

9 Mersky H, Shafran B. Political hazards in the diagnosis of "sluggish schizophrenia." $\mathrm{Br} f$ Psychiatry 1986;148:247-56.

10 Bukovsky V, Gluzman S. A manual on psychiatry for dissidents. Reprinted from Survey (London) Winter/Spring 1975, for distribution by the Working Group on the Internment of Dissenters in Mental Hospitals.

11 Working Group on the Internment of Dissenters in Mental Hospitals. The political abuse of psychiatry in the Soviet Union. London: Working Group on the Internment of Dissenters in psychiaty in the Soviet Unio.
12 Podrabinek A. Punitive medicine. Ann Arbour: Karoma Publishers, 1979.

13 Koryagin A. Unwilling patients. Lancet 1981 ; i:821-4.

14 Snezhnevsky AV. The symptomatology, clinical forms and nosology of schizophrenia. In Howells JG, ed. Modern perspectives in world psychiatry. London: Oliver and Boyd, 1968:425-47. Howelis JG, ed. Modern perspectives in world psychiatry. London: Oliver and Boyd, 1968:425-47.
World Health Organisation. Report of the international pilot study of schizophrenia. Vol 1. Geneva: World Health Organisation. Report of
World Health Organisation, 1973.

World Health Organisation, 1973 .
Berner P, Gabriel E, Katschnig H, et al. Diagnostic criteria for schizophrenic and affective psychoses. Washington: Distributed by American Psychiatric Press for the World Psychiatric Association, 1983.

17 Jablensky A. Epidemiology of schizophrenia: A European perspective. Schizophr Bull 1986;12: 52-73.

18 World Health Organisation. Mental disorders: glossany and guide to their classification in accordance with the Ninth Revision of the International Classification of Diseases. Geneva: World Health Organisation, 1978.

19 Working Group on the Internment of Dissenters in Mental Hospitals. Dr Semyon Gluzman: the imprisoned conscience of Soviet psychiatry. London: Working Group on the Internment of Dissenters in Mental Hospitals, 1977.

20 Windholz G. Psychiatric commitments of religious dissenters in Tsarist and Soviet Russia: two case studies. Psychiatry 1985;48:329-40

1 Chekhov AP. Ward 6. In: Lady with lapdog and other stories. Harmondsworth: Penguin, 1964.

Kaser M. Health care in the Soviet Union and Eastern Europe. London: Croom Helm, 1976.

23 Ryan M. The organisation of Soviet medical care. Oxford: Basil Blackwell and Martin Robertson, Ryan M.

24 Galach'yan AG. Soviet Union. In: Kiev A, ed. Psychiatry in the communist world. New York: Science House, 1968:29-50.

25 Brown BS, Kopin IJ, Kramer M, et al. The 1972 NIMH mission to assess schizophrenic research in the USSR. In: Brown BS, Torrey EF, eds. International collaboration in mental health. Rockville: National Institute of Mental Health, 1973:17-25.

26 Corson SA, Corson EO'L, eds. Psychiatry and psychology in the USSR. New York: Plenum Press, 1976.

27 Mombour W. Comparison between different systems of psychiatric education including some aspects on the ideology of different mental health systems. In: Alino JJL-I, Lenz G, eds. Training and education in psychiatry. Wien: Facultas Verlag, 1984:306-17.

28 Miller MA. The theory and practice of psychiatry in the Soviet Union. Psychiatry 1985;48:13-24. 9 Babayan E. The structure of psychiatry in the Soviet Union. (In collaboration with YuG Shashina.) New York: International Universities Press, 1985.

30 Brockington IF, Kendell RE, Leff JP. Definitions of schizophrenia: concordance and prediction of outcome. Psychol Med 1978;8:387-98.

of outcome. Psychol Med 1978;8:387-98.
. International Pilot Study of Schizophrenia. Psychol Med 1977;7:529-41.

32 World Health Organisation. Schizophrenia: an international follow-up study. Chichester: John Wiley, 1979

\section{A star treatment for digoxin overdose?}

The conventional management of intoxication with cardiac glycosides is unsatisfactory. Supportive measures and cardiac pacing are the mainstays as attempts to increase the elimination of glycosides have not been successful. The development of digoxin antibodies for measuring concentrations of this drug and the subsequent demonstration of their ability to abolish digoxin toxicity in animals ${ }^{1}$ were therefore potentially important advances.

The antibodies were first used in man in $1976,{ }^{2}$ but production problems have severely restricted supplies. ${ }^{3}$ However, Digibind (Wellcome Foundation Ltd) is now generally available in Britain, and Digitalis Antidote BM (Boeringher Mannheim $\mathrm{GmbH}$ ) has already been released in Europe. ${ }^{4}$ These digoxin specific antibodies are raised in sheep and cross react with digitoxin ${ }^{46}$ and lanatoside C. Giving intact immunoglobulins is unnecessary; digoxin specific Fab fragments obtained by cleaving whole antibodies are sufficient. These should distribute rapidly into a large volume as they have a small mass- 50000 daltons. They should also be less immunogenic than whole antibodies because antigenic determinants and complement binding sites are eliminated.

Assessing their efficacy in a controlled trial seems superfluous. Sixty three patients with severe poisoning - that is, with life threatening arrhythmias or hyperkalaemia, or bothwere given the Wellcome preparation intravenously over 15-30 minutes. They ranged in age from a few days to 85 years and included 28 who had taken massive overdoses. Fifty three of the 56 patients suitable for analysis recovered 